\title{
Disaster and Change in an Ottoman Sephardic Community: Moses Montefiore and the Monastir Fire of 1863
}

\author{
MARK COHEN ${ }^{1}$ \\ Piedmont, California
}

I n August 1863, the Ottoman city of Monastir suffered a fire that destroyed its Jewish quarter, and this event has been mentioned in nearly all the works that treat the Monastir Jews. ${ }^{2}$ But all the accounts overlook an important story that sheds light on what historian Aron Rodrigue has shown to be one of European Jewry's more important nineteenth-century endeavours: the 'regeneration' of the Ottoman Sephardim. ${ }^{3}$ After the fire, Monastir's rabbinical leadership sought the help of London's Sir Moses Montefiore, who encouraged British Jewry to make donations on behalf of Monastir's 3,000 homeless Jews. More than $£ 2,000$ was raised. But London did not allow the money to be used to rebuild the traditional Talmud Torah school. It was a revealing if not surprising decision. By the mid-nineteenth century, the Jews of France and England were keen to overhaul the education of the Sephardic Jews in order to prepare them for life as citizens in a rapidly Westernising Ottoman society. The Talmud Torah schools, which focused exclusively on Hebrew and Talmud, were seen as hindering that goal. In Monastir, British Jewry's refusal to aid the Talmud Torah helped tip the balance of power away from traditionalist rabbis toward a small group of educational reformers. Within a year, these reformers founded one of the first committees in the Ottoman Empire to support the kind of schools favoured by Western Jews - those of the Alliance Israélite Universelle.

London's decision to financially starve a Jewish school it viewed as backward typified Western Jewry's mid-nineteenth-century dealings with the Ot-

1 Mark Cohen is the author of Last Century of A Sephardic Community: The Jews of Monastir, 1839-1943, published by The Foundation for the Advancement of Sephardic Studies and Culture (New York).

${ }^{2}$ Moise Franco, Essai sur l'histoire des Israelites de l'Empire Ottoman depuis les origines jusqu'a nos jours (Hildesheim, New York, 1973), p. 206; 'Monastir', in The Jewish Encyclopedia (Funk \& Wagnalls, New York, 1903-1906), vol. 8, p. 654; 'Monastir', in Encyclopaedia Judaica (Encyclopaedia Judaica, Jerusalem, 1971), vol. 12, p. 239; Max A. Luria, A Study of the Monastir Dialect of Judeo-Spanish Based on Oral Material Collected in Monastir, Yugo-Slavia (Instituto de las Españas en los Estados Unidos, New York, 1930), p. 5; Gorgi Dimovski-Colev, The Bitola Jews (Society of Science and Art, Bitola, 1993), pp. 78-79; Jenny Lebl, Ge'ut va-shever: perakim be-toldot Yehude Makedonyah ha-Vardarit (Moreshet, Jerusalem, 1986), p. 46; Albert Montefiore Hyamson, The Sephardim of England: a history of the Spanish and Portuguese Jewish Community, 1492-1951 (Spanish and Portuguese Jews' Congregation, London, 1991), p. 384. The notable exception is Uri Oren, A Town Called Monastir (Dror Publications, Tel Aviv, 1971).

3 Aron Rodrigue, French Jews, Turkish Jews: The Alliance Israélite Universelle and the Politics of Jewish Schooling in Turkey, 1860-1925 (Indiana University Press, Bloomington/Indianapolis, 1990), pp. 3-4, 14-15. 
toman Sephardim. The Jews of Western Europe - sensitive to their tenuous hold on recently won civil rights and social acceptance - were made uneasy by the traditionally religious, socially segregated, Spanish-speaking Ottoman Jew, whose proximity seemed to increase as European influence expanded. For west European Jews, the answer both to their own unease and to the Sephardim's non-integration into Ottoman society was education of the sort that had led to their own (ongoing) acceptance in England and France. Ottoman Jews needed to be 'regenerated' through instruction in west European languages and useful trades. To achieve this end, the authority of their rabbis also needed to be undermined. ${ }^{4}$

To implement this agenda, pressure was applied. Opportunity knocked when Ottoman Jews were needy, and Western Jews could leverage charitable aid to gain ideological ground. The unknown story of London's aid to Monastir (today's Bitola, Macedonia) is a revealing example of how this process worked. In the story of Monastir, we can learn more about how west European Jews transformed charitable aid into financial pressure for educational reforms - how the money was controlled, what aspects of the aid were publicised and which were kept secret, and what effects - intended and unintended-resulted. It also offers an insight into the west European Jew's fierce attachment to the programme of educational betterment, which he would not abandon even in the face of entreaties from a suffering community.

\section{Western Jews and Sephardic Schools, 1840-1863}

By 1863, the efforts of European Jewry to reform the exclusively religious schools of the Ottoman Sephardim were well established. Since 1840, when the Damascus Affair blood libel accusation brought leading French and British Jews to the Middle East to free captive Jews, west European Jews had made it clear that they disapproved of the Sephardim's traditional Talmud Torah schools. Adolphe Crémieux represented French Jewry, and while in Alexandria, Egypt, to petition Mehmet Ali, ruler of Damascus, he delivered a sermon at a local synagogue that advocated teaching a European curriculum. From Alexandria he proceeded to Cairo, where he founded the first Jewish schools in the Middle East to teach European languages and other secular subjects. (The schools closed soon after Crémieux's departure.) Montefiore represented British Jewry, and during his visit to Istanbul he also devoted himself to the need for educational reforms. He was disturbed to find that Sephardic schools focused solely on the study of Hebrew and the Talmud, which students translated into their native Judeo-Spanish. Montefiore met with Istanbul's Jewish leaders, 'rebuked them for their unwisdom in concentrating all their energies on the study of Hebrew', and pressed the Ottoman Chief Rabbi, Mosheh Fresco, to issue on 28 October 1840 a proclamation urging all Jewish schools in the Empire to hire teachers of Turkish. ${ }^{5}$ (When it

\footnotetext{
4 Ibid., pp. 8-13.

${ }^{5}$ Ibid., pp. 3-4.
} 
came to reforming Ottoman Jewish education, both the French and Turkish languages had their advocates. But the commercial might of Europe made the acquisition of French a necessity for anyone hoping to do business in the Ottoman Empire, while Turkish was useful only for Ottoman civil service work that was largely controlled by Armenians, and of little interest to Jews.) ${ }^{6}$

As Rodrigue has noted, Crémieux and Montefiore's actions marked a new departure in the relations between emancipated Jews in countries such as France and England, and the traditional Jewish communities of less open societies. Charitable help among Jewish communities was an established tradition that had never before required the recipient to implement social reforms. But in 1840 west European Jews - encouraged by the Ottoman reform decree of 1839 that seemed to legally emancipate the Empire's Jews, and confident that their own experience with emancipation and acculturation could serve as a model for the Sephardim-leveraged their financial resources and cultural influence by urging reforms during a moment of crisis. 'Intercession on behalf of fellow Jews in distress and philanthropy had now become politicized', wrote Rodrigue. 'The aim was not only to give help when called upon but also to transform, "regenerate",?

This regeneration of the Sephardic Jew required his complete transformation. As one reformer put it, the Sephardic Jew 'must change his views, his habits, his manners, and his language' ${ }^{8}$ Schools teaching west European languages were to help effect this change, and during the 1850s French and British Jews, with the help of like-minded Italian Jewish merchants resident in the Ottoman Empire, founded such schools in the Sephardic centres of Istanbul, Izmir, Edirne, and Salonica. With the exception of the Istanbul school, founded in 1854, all of the schools were established after the second Ottoman reform decree of 18 February 1856 . This decree more explicitly guaranteed the rights of non-Muslims, and the prospect of such equality and acceptance encouraged west European Jews to believe that another branch of world Jewry was about to follow in their footsteps on the road to emancipation and citizenship. To speed and complete the process, they called upon the Ottoman Sephardim to reform their schools, and also founded new Jewish schools to spread among the Sephardim the French language and culture. Traditionalist Ottoman rabbis opposed the secular schools and closed many, but this early work of Jewish educational reform 'had prepared the ground for the Alliance. ${ }^{9}$.

The Alliance Israélite Universelle was founded in Paris in 1860, and in 1863 Crémieux became its president and once again strove to introduce French instruction among the Sephardim. In November 1863, he traveled to Istan-

\footnotetext{
6 Ibid., p. 86; Charles Issawi, 'Introduction', in Dimitri Gondicas and Charles Issawi, eds, Ottoman Greeks in the Age of Nationalism: Politics, Economy, and Society in the Nineteenth Century (The Darwin Press, Princeton, 1999), pp. 3-4.

7 Rodrigue, French (as in n. 3), p. 4.

8 Aron Rodrigue, 'The Beginnings of Westernization and Community Reform Among Istanbul's Jewry, 1854-65', in Avigdor Levy, ed., The Jews of the Ottoman Empire (The Darwin Press, Princeton, 1994), p. 444. The reformer was Istanbul's Abraham Camondo.

${ }^{9}$ Rodrigue, French (as in n. 3), pp. 39-45.
} 
bul to inaugurate the Regional Committee of the Alliance in Turkey and urge other communities to found Alliance committees. Salonica and Izmir founded committees in 1863, and in 1864 committees opened in Gallipoli, Volos, and Monastir. ${ }^{10}$ The modern Jewish schools founded in the 1850s made Istanbul, Salonica, and Izmir natural sites for early Alliance committees, and Volos and Gallipoli were small port cities close to Salonica and Istanbul, respectively, that appear to have been influenced by the major Jewish centres. The Faraggis of Volos, for example, were in contact with Yehuda Nehama, a leading Salonica reformer. ${ }^{11}$

Monastir did not see the founding of new Jewish schools in the 1850s, and it was not a major Sephardic centre, either in population or achievements. ${ }^{12}$ It was not a port city, and its location in the mountains of Macedonia made it inaccessible to travellers from Salonica - its nearest great neighbour-for much of the year. ${ }^{13}$ It also was never visited by European-Jewish reformers, who founded modern schools elsewhere in the Empire. ${ }^{14}$

Despite these deprivations, west European trends in education, dress, and leisure did infiltrate Monastir and attract the attention of some in the Jewish community. As in other Sephardic centres, conditions in Monastir were becoming ripe for educational reform. But because of the community's obscurity, west European Jews did not focus on it until, in a moment of need, Monastir called out for help. In crucial ways, the Monastir fire replicated some key conditions of the Damascus Affair of 1840. As with the Damascus Affair, the Monastir fire caused Ottoman Sephardim to reach out to their more wealthy and powerful brethren in Western Europe. And as in 1840, Western Jewry saw in the devastation at Monastir an opportunity to use its wealth and influence to not only give help but also to transform.

\section{Westernisation at Monastir}

The efforts of European Jewry to introduce west European languages and curriculum among the Ottoman Sephardim took place in the context of a more general triumph of Western cultural modes in the Ottoman Empire. The Westernising policy of the Ottoman Empire - defined by Bernard Lewis as the 'imitation and adoption of certain selected elements from the civilization of Western Europe'- during the eighteenth and nineteenth centuries radically

\footnotetext{
10 Ibid., pp. 22, 47-48. For the Monastir committee, see Bulletin de L'Alliance Israélite Universelle (hereafter BAIU), October 1864, p. 7. Also see, Lebl, Ge'ut (as in n. 2), p. 126.

11 Rodrigue, French (as in n. 3), p. 49.

12 In the mid-nineteenth century there were 150,000 Jews in the Ottoman Empire. Monastir's 3,000 Jews accounted for only 2 per cent of that population. In addition, the greatest Sephardic Talmud Torah school was in Salonica. See Rodrigue, French (as in n. 3), pp. 26, 36. For Monastir's Jewish population, see Dimovski-Colev, Bitola (as in n. 2), p. 34. For equivalent 600 Jewish families in Monastir, see PRO-FO 78/1764, Charles Calvert to The Earl Russell, August 20, 1863, p. 241.

13 Annales de la Congregation de la Mission (hereafter Annales) 23 (1856-1857), pp. 223-24; Basil C. Gounaris, Steam Over Macedonia, 1870-1912: Socio-economic change and the railway factor (East European Monographs, Boulder, Colo., 1993), pp. 35-36.

14 Rodrigue, French (as in n. 3), p. 15, and Rodrigue, 'Beginnings' (as in n. 8), p. 441.
} 
transformed the customs, laws, government structure, and army of the Islamic society. ${ }^{15}$ Monastir was a showcase of the Empire's adoption of European ways.

On 17 September 1848, after four days of overland travel from Salonica, the English writer and painter Edward Lear arrived in Monastir. Nearly all the towns he encountered along the way were tattered and dirty. They were no preparation for Monastir.

Anticipating — as in every previous case during this journey - that the glitter and beauty of outward appearance would be exchanged on entering the city for squalor and dreariness, I was agreeably surprised at the great extent of public buildings, barracks, and offices at the entrance of the town, and, within it, at the width and good pavement of the streets, the cleanliness and neatness of the houses .... [T] he bustle and brilliancy of Monastir is remarkable, and its effect appeared particularly striking coming to it, as I did, after passing through a wild and thinly peopled region. You are bewildered by the sudden reappearance of a civilization which you had apparently left for ever: reviews, guards, bands of music, pashas, palaces, and sentry-boxes, bustling scenes and heaps of merchandise await you at every turn. ${ }^{16}$

In the middle of the nineteenth century Monastir was an oasis of Western civilisation. From 1839 to 1863, while the Ottoman Empire endured war and economic decline, Monastir enjoyed twenty-five years of peace and prosperity. Though it was never on a par with the great Ottoman cities of Istanbul and Izmir, during the 1840s and 1850s Monastir nearly matched Salonica in size and surpassed it in modern attainments. ${ }^{17}$ And in its remote Macedonian highlands Monastir had no peer or rival. As the administrative and military capital of much of European Turkey, the city had it all: vibrant commerce, military power, impressive architecture, a cultured elite, political clout. Without a port or rail link, set at the foot of mountains in a mountainous region, and separated from the regional metropolis of Salonica by four days on horseback, Monastir managed to become an energetic and affluent city of 45,000 people. These included about 22,000 Muslims, 3,000 Jews, 1,500 Catholics, 2,500 Gypsies, and 17,000 members of the Greek Orthodox Church. ${ }^{18}$

15 Bernard Lewis, The Emergence of Modern Turkey (Oxford University Press, Oxford, 1969), 2nd edn, pp. 45, 127-28.

${ }^{16}$ Edward Lear, Journals of a Landscape Painter in Greece and Albania (Century, London, 1988), pp. 17, 22, 24-34, 36.

17 Kemal H. Karpat, Ottoman Population 1830-1914: Demographic and Social Characteristics (University of Wisconsin Press, Madison, Wisc., 1985), pp. 103, 47; Nikolai Todorov, The Balkan City, 1400-1900 (University of Washington Press, Seattle, 1983), p. 313; Alexandra Yerolympos, Urban Transformation in the Balkans (1820-1920): aspects of Balkan town planning and the remaking of Thessaloniki (University Studio Press, Thessaloniki, Greece, 1996), p. 61; Viktor Ivanovich Grigorovich, Ocherk za puteshestvie po evropeiska Turtsiia (BAN, Sofiia, 1978), p. 94.

18 B. Nikolaïdes, Les Turcs et la Turquie Contemporaine; itinéraire et compte-rendu de voyages dans le provinces ottomanes avec cartes detaillées (F. Sartorius, Paris, 1859), vol. 2, p. 159; The Presbyterian, A Missionary and Religious Record of the Presbyterian Church of Canada in Connection With the Church of Scotland 14:2 (February 1861), p. 22. I have used the 45,000 figure and adjusted upwards the group populations in Bernard Lory and Alexandre Popovic, 'Au carrefour des Balkans, Bitola 1816-1918', in Paul Dumont and Francois Georgeon, eds, Villes Ottomanes a la Fin de L'Empire (L'Harmattan, Paris, 1992), p. 83. 
Monastir was an ideal Turkish city of the Westernising Ottoman Empire. The years 1839-1878 were the age of Tanzimat, a period of Ottoman reforms that proposed to increase the wealth and strength of the Empire by imposing on it "practices and procedures derived from Europe, with the encouragement, if not the insistence, of European powers, and with the help of European experts and advisers'. ${ }^{19}$ Turkish cities were prime targets of this agenda. As early as 1836, before the first Ottoman reform decree of 3 November 1839, Turkey's most powerful reform advocate, Mustafa Reshid Pasha, urged the reengineering of Ottoman cities along European lines. From the layout of the streets to architectural styles to building materials, everything was to reflect 'the new style that is in vogue in Europe'. ${ }^{20}$

The whole of this programme was in evidence at Monastir, which a halfcentury of events had conspired to bring to prominence. A turning point was the early nineteenth-century destruction, by Ali Pasha of Janina, of the Macedonian city of Moschopolis, which caused its talented and energetic Vlach population to seek refuge in Monastir. ${ }^{21}$ In 1816, in an effort to secure the Empire's hold on Macedonia in the wake of Belgrade winning autonomy the year before, Sultan Mahmud II made Monastir the military headquarters of Rumelia, the largest province of European Turkey. In addition, political power came to Monastir in the wake of its new military status. In 1831, Monastir was made the capital of Rumelia, a province that held 2 million people and stretched nearly 500 miles from the Adriatic sea in the west to Istanbul in the east. ${ }^{22}$ Monastir was assigned a governor-general (derebey or pasha), who resided in a palace.

Finally, a massive rebuilding effort following a fire in 1835 brought to Monastir an approach to city planning that the Ottomans had lately borrowed from Europe. The city's streets were widened and homes were updated, but the most dramatic architectural testament to Monastir's transformation was its army complex. A barracks and military hospital that were immense and extraordinary for their time were strategically placed on the heights southwest of town to impress arriving visitors. Employing a European neo-classical style and completed by May 1839, the barracks anticipated the spirit of the Ottoman reforms introduced by the sultan in November of that same year. The reforms promised respect for property and equal treatment

\footnotetext{
19 Lewis, Emergence (as in n. 15), p. 127.

20 Diana Barillari and Ezio Godoli, Istanbul 1900: art-nouveau architecture and interiors (Rizzoli, New York, 1996), p. 11. For reformer, see Lewis, Emergence (as in n. 15), pp. 105-106.

21 T. J. Winnifrith, The Vlachs: The History of a Balkan People (London, 1987), map no. 12, n.p.; N. Pantazopoulos, 'Community Laws and Customs of Western Macedonia Under Ottoman Rule', Balkan Studies 2:1, p. 12; Katherine Elizabeth Fleming, Ali Pasha of Ioannina: A Study in Cultural Representation (PhD dissertation, University of California, Berkeley, 1995), p. 43; George Prevelakis, 'The Return of the Macedonian Question', in F. W. Carter and H. T. Norris, eds, The Changing Shape of the Balkans (Boulder, Colo., 1996), p. 135.

22 For army headquarters in 1816, see Lory and Popovic, 'Carrefour' (as in n. 18), p. 79. For population and extent of Rumelia, see Karpat, Ottoman (as in n. 17), pp. 8, 14-15, 93, 109; and Joseph Muller, Albanien Rumelien, und die Österreichisch-montenegrische Gränze: oder statistischtopographische Darstellung der Paschaliks Skutari, Ipek, Toli-Monastir, Jakova, Tirana, Kavaja, Elbassan und Ohrida, so wie das Gränzdistricts von Budua in Österreichisch-Albanien (J. G. Calve, Prag, 1844) p. 87.
} 
for non-Muslim subjects. It signaled a new era, and Monastir's new buildings announced to travellers that they had arrived in the city of the future. In 1839, Monastir emerged as among the most Europeanised Turkish towns of the early Tanzimat era. In its city centre that comprised straight and broad European-style boulevards, in its public and private architecture that borrowed neo-classical elements, and in its European-educated civic and military leadership Monastir was a model of the Westernising efforts of the Ottoman Empire. $^{23}$

The city so outpaced other Balkan towns that it surprised the most seasoned travellers. In 1858, the German scholar J. G. von Hahn had almost completed his journey from Belgrade to Salonica when he arrived in Monastir, but nothing he had seen prepared him for Monastir's vast and immaculate army barracks and modern military hospital, which did 'not by any means need to shy away from a comparison with the best European hospitals' ${ }^{24}$ Even European visitors who had little sympathy for the Ottoman Empire, and who indicted its corrupt bureaucracy for breeding inertia among its subjects, had a soft spot for Monastir. They praised its industrious atmosphere and compared it favourably to the legendary Ottoman capital. In 1860, the English traveller Mary Walker looked out of the window of the British Consulate in Monastir, observed the constant passing of 'long strings of camels and beasts laden with merchandise', and felt that the city displayed a 'bustle and an activity which looked more westerly, and gave the place a far more civilised aspect in some respects than even Constantinople itself ${ }^{\prime 25}$

Education based on the west European model had also made inroads at Monastir, especially among the city's 17,000 Greeks. They had instituted secular schooling to replace traditional religious instruction as early as 1830 , and in 1851 they augmented such instruction by hiring the German-educated Margaritis Demista, a renowned scholar and author of celebrated archaeological studies on Macedonia, to run a new school founded that year. ${ }^{26}$ Subjects included geography, French, arithmetic and history as well as Socrates and Homer. In addition, the Ottoman military in 1855 began operating schools that incorporated a west European curriculum in order to educate future officers. Monastir's army headquarters had one of these schools as early as 1858. In the 1860s, this school educated Manastirli Mehmed Rifat, one of

${ }^{23}$ For fire and rebuilding, see Lebl, Ge'ut (as in n. 2), p. 45; Ami Boue, La Turquie d'Europe (A. Bertrand, Paris, 1840), vol. 3, p. 69; and Mark Cohen, 'Monastir: Oasis of Civilization, 1839-63', The Turkish Studies Association Bulletin 24:2 (Fall 2000), pp. 19-21. For later transformation of other cities, see Barillari and Godoli, Istanbul (as in n. 20), pp. 14-15; Z. Celik, The Remaking of Istanbul (University of Washington Press, Seattle/London, 1986), pp. 3, 53; Yerolympos, Urban (as in n. 17), pp. 79, 62-63, 50, 52; Beatrice Saint-Laurent, 'Un amateur de theatre: Ahmed Vefik pacha et le remodelage de Bursa dans le dernier tiers du XIX siecle', in Dumont and Georgeon, eds, Villes (as in n. 18), p. 99.

24 J. G. von Hahn, Reise von Belgrad nach Salonik (Akademie der Wissenschaften, Vienna, 1861), pp. 115, 117-18. For barracks, see Lory and Popovic, 'Carrefour', (as in n. 18), p. 81

25 Mary Adelaide Walker, Through Macedonia to the Albanian Lakes (Chapman \& Hall, London, 1864), pp. 133-34, 88, 136.

26 For Greek schools, see Stephanos J. Papadopoulos, 'Ecoles et Associations Grecques dans la Macedoine du Nord durant le dernier siècle de la domination Turque', Balkan Studies 3 (1962), pp. 399-400. For Demista, see Vasili Gounaris to Mark Cohen, 18 Dec. 2000. 
Turkey's more successful Westernised playwrights. ${ }^{27}$

Monastir was a vibrant centre of the Ottoman reforms. European languages, dress, pastimes, and education abounded.

\section{Traditional Life in the Jewish Quarter}

Alongside this headlong embrace of European civilisation, Monastir's Jewish quarter was a world apart. In the middle of the nineteenth century, Monastir was one of the greatest preserves of traditional Sephardic culture, language, and folklore in all the Ottoman Balkans. Medieval Spanish ballads were cherished in Monastir, and songs that were forgotten by other Ottoman Sephardim were still recited in Monastir. ${ }^{28}$ Women who could not read recited lengthy and complex folktales from memory, hundreds of proverbs that shrewdly and comically located life's truths were a common possession, and an unusually old Spanish pronunciation and vocabulary was prevalent in Monastir's Judeo-Spanish language. ${ }^{29}$ This Sephardic folk culture was intertwined with and inseparable from Jewish religious faith and practice. Rabbinical authority was formidable, religious faith was deep, and synagogues, Jewish law courts, and religious schools were the community's primary institutions. ${ }^{30}$ During the period that saw Monastir Westernise, the Jewish quarter remained a bastion of tradition.

Some Jews participated in the revival of Monastir's commerce, and the Jewish community as a whole benefited from the wealth accumulated by a few of its members, but Monastir's Jewish society was largely unchanged by the innovations that surrounded it. Throughout the Ottoman Balkans, from Istanbul to Salonika and from Izmir to Rhodes, the Tanzimat's reforms overlapped with the last years of a traditional Sephardic culture that had shaped Jewish life and learning for centuries. The Tanzimat was at odds with this traditional culture, but the Ottoman government did not make the transformation of its 150,000 Sephardim a top priority. To meet the military and commer-

${ }^{27}$ For curriculum, see Presbyterian (as in n. 18) 13:8 (August 1860), p. 116, and Nikolaïdes, Turcs (as in n. 18), vol. 2, p. 160. For military schools, see David B. Ralston, Importing the European Army: the introduction of European military techniques and institutions into the extraEuropean world, 1600-1914 (University of Chicago Press, Chicago, 1990), pp. 64-65. For military school in Monastir, see Hahn, Reise (as in n. 24), p. 118. For playwright, see Encyclopedia of Islam (Brill, Leiden, 1991), vol. 6, pp. 372-73.

${ }^{28}$ Samuel G. Armistead and Joseph H. Silverman, 'Judeo-Spanish Ballads From Monastir, Yugoslavia', in Josep M. Sola-Solé, Samuel G. Armistead, Joseph H. Silverman, eds, Hispania Judaica: Studies on the History, Language, and Literature of the Jews in the Hispanic World (Puvill Libros S.A., Barcelona, 1982), vol. 2, p. 13.

29 C. Crews, 'Judaeo-Spanish Folktales in Macedonia', Folk-Lore 43 (1932), p. 196; Max A. Luria, 'Judeo-Spanish Proverbs of the Monastir Dialect', Revue Hispanique 81 (1933), pp. 25671; Luria, A Study (as in n. 2), p. 10.

30 For Sephardic faith, see Rodrigue, French (as in n. 3), pp. 35, 38, and Rufus Anderson, History of the Missions of the American Board of Commissioners for Foreign Missions (Congregational Publishing Society, Boston, 1875), vol. 4, p. 166. For rabbis, see M. A. Ubicini, Letters on Turkey (Arno Press, New York, 1973), vol. 2, p. 360, and Ilan Karmi, The Jewish Community of Istanbul in the Nineteenth Century: social, legal and administrative transformations (Isis Press, Istanbul, 1996), pp. 13-14, 38. For religious court, see Lebl, Ge'ut (as in n. 2), p. 114. 
cial challenges posed by Europe, the Empire compelled Western education among Muslims, and it benefited from the European orientation of its 2 million Greeks and 2.4 million Armenians, who as Christian groups with active merchant classes were attracted to Western Europe. Neither force was at work among the Jews. The government did not pressure them to learn French or other secular disciplines because the Jews' small numbers and general poverty made them relatively unimportant to the Empire. And the Sephardim, for their part, had no inherent sympathy with Christian Europe. ${ }^{31}$ Unlike the Muslims and Christians, the Jews were neither pushed nor pulled toward Europe.

The conditions that kept west European culture distant from the Jews allowed their traditional religious schools and practices, as well as their JudeoSpanish language and folklore, to survive decades of Ottoman reform. In Monastir, this traditional culture was well preserved, and it enjoyed the protection and privacy of the Jewish mahalle, a walled and self-contained residential district that was home to the city's 3,000 Jews. ${ }^{32}$

\section{The Jewish Quarter}

The entrance to the Jewish mahalle separated more than it connected the Jews to the rest of Monastir. The narrow, gated passageway set between two houses was meant to restrict traffic, not encourage it, and it seemed to promise access only to a warren of similar alleys. But once past this corridor Monastir's Jewish world expanded. The centre of the Jewish quarter was a large courtyard surrounded and enclosed by the houses, which presented their backs to Monastir. This was 'The Great Court', known to the Ottomans since 1656 as buyuk havli, and called cortijo by the Sephardim. ${ }^{33}$ Individual homes around the courtyard were little more than a room or two in which several generations of a family slept and ate, and indoor kitchens were almost unheard of in Monastir, so the courtyard served as an extension of the crowded residence and a host to domestic life. ${ }^{34}$

Though Jews in the Ottoman Empire were never forced to live in separate sections of their cities, as they were in Christian Europe, it was common for

\footnotetext{
31 For Muslims, see Lewis, Emergence (as in n. 15), pp. 101, 113-14. For Greeks and Armenians, see Issawi, Introduction (as in n. 6), p. 2. For Greeks, Armenians, and Jews, see Rodrigue, French (as in n. 3), pp. 25, 26, 41, 43-44, 45-46.

32 Dimovski-Colev, Bitola (as in n. 2), p. 34; PRO-FO 78/1764 (as in n. 12), Calvert to Russell, p. $241 \mathrm{ff}$.

33 Dimovski-Colev, Bitola (as in n. 2), p. 34, and Alexandra Yerolympos, 'New Data Relating to the Spatial Organisation of the Jewish Communities in the European Provinces of the Ottoman Empire (19th c.)', in I. K. Hassiotis, ed., The Jewish Communities of Southeastern Europe: From the Fifteenth Century to the End of World War II (Institute for Balkan Studies, Thessaloniki, Greece, 1997), p. 631.

${ }^{34}$ For lack of kitchens, see Walker, Through (as in n. 25), p. 140. For a Jewish courtyard, see Panayotis Gr. Tsolakis, 'The Residential Organisation of the Jews in Kastoria', in Hassiotis, ed., Jewish (as in n. 33), p. 539. For size of residences and families, see Harriet Pass Freidenreich, The Jews of Yugoslavia: A Quest for Community (Jewish Publication Society, Philadelphia, 1979), p. 12.
} 
Jews to live in enclaves of their own. The cortijo housed the Jews as a community, and this communal separateness corresponded well to the arrangement of Ottoman society, which recognised its subjects as members of religious groups. The mahalle also had advantages for the organisation of Sephardic society. Like all communities, it upheld its values through a combination of social pressure and formal policing, both of which were easily accomplished in the cortijo. With everyone exposed to the eyes and judgements of their neighbours, people were sure to conform to social norms, such as regular synagogue attendance. ${ }^{35}$ In addition, special wardens known as berurei averot patrolled the quarter to suppress and report religious transgressions, a practice imported from Spain that was unknown outside Sephardic communities. According to a witty Monastirli proverb, the Jewish quarter was all-knowing: Dil Dió y dil vizinu no si puedi nade incuvrir (From God and from the neighbour one can't hide anything). ${ }^{36}$

While the girls stayed home and received an education through Sephardic folk culture, Monastir's Jewish boys began their religious education at la skolika, a kind of nursery school run by a woman known as la maestra. This school catered to boys between the ages of three and six and introduced them to Jewish songs and prayers. Formal education began at Monastir's Talmud Torah school, where students mastered the Hebrew alphabet, learned to read the Torah, and then translated each word into Judeo-Spanish so its stories and lessons could be understood. Students also learned the daily prayers and, at more advanced levels, studied the Jewish legal commentaries of the Talmud. No secular studies, such as grammar, mathematics, history or Western languages were offered. Instruction in trades or crafts also had no place in the school. These were learned in the market or through membership in a guild. The purpose of the Talmud Torah was to instill Jewish faith and so ensure the survival of the Jewish people. In the period before 1863, there was one Talmud Torah in Monastir, and it provided the only education that Jewish boys received. ${ }^{37}$

It was not exactly a school. It was no more than one classroom consisting of very low benches. And the pupils would sit on top of soft pillow-like cloth which was laid on the floor high enough for us to reach the low benches .... The Talmud Torah was run by two teachers who made a living by teaching us ... the fundamentals of the Hebrew language. ${ }^{38}$

This description of Monastir's Talmud Torah is a recollection from the turn

35 Yerolympos, 'New' (as in n. 33), pp. 626, 628, and 634.

${ }^{36}$ For wardens, see Esther Benbassa and Aron Rodrigue, The Jews of the Balkans: The JudeoSpanish Community, fifteenth to twentieth Centuries (Blackwell, Oxford/Cambridge, Mass., 1995), p. 30. For proverb, see Luria, 'Judeo-Spanish' (as in n. 29), p. 260, no. 103.

37 For la skolika, see Lebl, Ge'ut (as in n. 2), p. 186. For maestras and Talmud Torah curriculum, see Rodrigue, French (as in n. 3), pp. 35-38. For maestra in Monastir, see Dimovski-Colev, Bitola (as in n. 2), p. 397. For one Talmud Torah, see Archives, Board of Deputies of British Jews (London), minute book, ACC/3121/A/9. Entry begins, 'Letter read from Consul Calvert dated from Monastir 25th March.'

38 Archives, Foundation for the Advancement of Sephardic Studies and Culture (New York), Leon Alcosser, My Life's Memoirs (New York, n.d.), p. 11. 
of the twentieth century, but it resembles scenes of Sephardic schooling from the mid-1800s. The practice of having students sit on the floor, as opposed to using chairs or benches, was the norm in mid-nineteenth-century Talmud Torah schools. In fact, during the years of the early Tanzimat period, the Sephardim specifically objected to the introduction of benches and desks because they were viewed as part of an irreligious Western culture. These objections were a small but telling indication of the distance that separated Jewish culture from Christian. As early as 1832, Armenian students in Izmir used chairs and desks. ${ }^{39}$

\section{Tradition and Poverty}

Tradition and its aversion to secular Western schooling contributed to widespread Jewish poverty, and poverty threatened this traditional Sephardic world with collapse. In Monastir, the poverty experienced by all Sephardic communities was exacerbated by the fire of 1835 . After the fire the Jews could not afford to pay the taxes they owed the local government, and they petitioned the pasha of Rumelia for an exemption. ${ }^{40}$

The period just after the fire was the community's low-point, and by the early 1860 s, after decades of active trade in Monastir, the Jews' economic conditions showed some improvement. In July 1863, the Church of Scotlandwhich had organised its 'Committee on the Conversion of the Jews' in 1838sent a missionary to the Jews of Monastir. Upon his arrival, Charles Stober wrote that half of the town's Jews, or about 300 families, were living decently. Still, at least 200 families were utterly destitute and depended on charity for their survival. Their living conditions were often terrible. Stober wrote that illness was common among the Jews, and that Mrs Stober, who acted as a nurse, 'nearly every day has visits from sick people, or visits them'. ${ }^{41}$

The disease was likely caused by malnutrition and poor hygiene, as it was in Sephardic communities elsewhere, but the situation was aggravated by overcrowding. About 3,000 people lived in the quarter's 200-plus houses, which were mostly one-storey structures, though some were taller. Given the ratio of 600 families to 200 houses, it is no surprise to learn from Stober that 'several families, sometimes as many as five, were crowded into one house'. ${ }^{42}$

Another cause of misery in the quarter was its physical setting. Though

39 Carter V. Findley, Ottoman Civil Officialdom: A social history (Princeton University Press, Princeton, 1989), pp. 140-41; James E. DeKay, Sketches of Turkey in 1831 and 1832 (J. \& J. Harper, New York, 1833), p. 498.

40 Dimovski-Colev, Bitola (as in n. 2), p. 69

41 Church of Scotland Home and Foreign Missionary Record (hereafter HFMR), 1 Oct. 1863, pp. 174-75, and 2 July 1877 , p. 414.

42 Paul Dumont, 'Jewish Communities in Turkey during the Last Decades of the Nineteenth Century in the Light of the Archives of the Alliance Israélite Universelle', in Benjamin Braude and Bernard Lewis, eds, Christians and Jews in the Ottoman Empire: The Functioning of A Plural Society (Holmes \& Meier, New York, 1982), vol. 1, p. 213. For the number of houses, see PROFO 78/1764 (as in n. 12), Calvert to Russell, p. 240, and Jewish Chronicle, 25 Sept. 1863, p. 5. For house sizes, see Dimovski-Colev, Bitola (as in n. 2), p. 34. For crowding, see HFMR (as in n. 41), 1 Oct. 1863 , p. 175. 
Ottoman Jews were not legally confined to their own part of the city, Jewish quarters were often located in the least desirable areas. According to one nineteenth-century observer, this was no accident. As the wife of a British consul, Mrs John Elijah Blunt lived in the Ottoman Empire for 20 years, from the 1850 s to the 1870 s. She wrote: '[b]oth in the capital and in provincial towns the Turkish quarter is invariably situated in the most healthy and elevated parts, and occupies, on account of the gardens belonging to almost every Turkish house, double the ground of the Christian and Jewish quarters' ${ }^{43}$

This sums up the situation in Monastir. Lear's description of Monastir's Jewish quarter-located, as Mrs Blunt could have predicted, in the lower part of town - reveals its problems. 'The stream, deep and narrow throughout the quarter of private houses and palaces, is spanned by two good stone bridges and confined by strong walls; but in the lower or Jew's quarter, where the torrent is much wider and shallower, the houses cluster down to the water's edge'. 44

Lear found the Jewish quarter picturesque, but the problems he described were serious. In the Jewish quarter the river was allowed to flood, damage property, or form stagnant malarial pools. These dangers were not hypothetical. Lear observed flood damage, and malaria was prevalent in Monastir and many Jews suffered from it. ${ }^{45}$ The lack of a walled channel to contain the river in the Jews' quarter is especially glaring in light of the improvements made in Monastir after the 1835 fire. The Jews obviously did not merit the upgrades that graced other parts of town. Further evidence of their low status is found in the name of the Jews' quarter. It was called Chufud, the derogatory Turkish word for Jew. ${ }^{46}$

Such Ottoman neglect compounded the economic hardships caused by Sephardic traditionalism. In 1860, the Presbyterian Church of Canada sent Ephraim Epstein, a converted Jew and medical doctor from New York, as a missionary to Monastir's Jews. Epstein noted the Jews' poverty and wrote, 'Want of work is the great cause of much of the evil existing among the Jews here. Another cause is a great fire which took place here some years ago, from which terrible calamity they are not able yet to recover' ${ }^{47}$ In the Jewish quarter the 1835 fire continued to sap the community's strength, while elsewhere in the city it was a catalyst for renewal.

\footnotetext{
43 Mrs John Elijah Blunt, The People of Turkey: Twenty years residence among Bulgarians, Greeks, Albanians, Turks, and Armenians/by a consul's daughter and wife (J. Murray, London, 1878), vol. 1, p. 216.

44 Lear, Journals (as in n. 16), p. 36.

45 For malaria, see National Library of Scotland, Archives, Church of Scotland (hereafter ACS), minute book, Dep 298/209, Report of 1873, n.p., and HFMR (as in n. 41), Dec. 2, 1878, p. 220.

46 Dimovski-Colev, Bitola (as in n. 2), p. 76. For chufud, see Muller, Albanien (as in n. 22), p. 86, and Benbassa and Rodrigue, Jews (as in n. 36), p. 33.

47 Presbyterian (as in n. 18) 14:2 (February 1861), p. 22.
} 


\section{Tradition and Charity}

Tradition's answer to the problem of poverty was tzedakah, or charity. By the mid-nineteenth century many poor Ottoman Sephardim, as well as institutions such as schools and synagogues, relied heavily on the support of a small class of wealthy Jews. ${ }^{48}$ In Monastir, affluent Jews were also crucial to the maintenance of the community. Though Jewish institutions remained largely unchanged during Monastir's revival, individual Jews did participate in and benefit from the city's business opportunities.

British consular reports note that the Jews were active in local trade, and important merchants included Jhiel Nahman Alevi, Salomon Nahman Alevi, Jacob Rahamim Nahmias, Joseph Mosé Orgas, and Joseph Haim Perrés. One unnamed Jewish merchant was singled out for attention because he owned a stone warehouse containing European goods worth $£ 5,000 .{ }^{49}$ Ten Jewish businesses operated as millers of flour, and 18 more sold barley and oats. Both businesses suited the agricultural production of the region. There were no banks in Monastir, so Salomon Abraham Camhi, Salomon Bochor Nahama, Salomon Abraam Sarfati, Aron Nessim, Avissay Raphael Alevi, Mair Abraham Alevi, Haim Benjamin Estrumtza, Salomon Isaac Francés, and Nahman Jacob Mulia acted as bankers by making small loans. ${ }^{50}$ Monastir's role as a government centre also brought some Jews wealth and position. In 1833, Salomon Bazirgan served as city treasurer and received the highest salary paid by the local government. ${ }^{51}$

The vital role played by these more affluent Jews is made clear by Rev. Stober's report that 200 families depended upon charity to survive. The wealthy also paid the taxes owed by the poor. British Consul Charles Calvert wrote that the burden of Ottoman taxes fell on the wealthier Monastir Jews, 'through whose united efforts their indigent brethren have hitherto been relieved from the payment of this [military exemption tax] as well as of nearly every other tax assessed upon their community'. ${ }^{52}$ Such largesse was not seen in every Sephardic community, even in the mid-1800s. In 1847, the poor Jews of Izmir were exploited by the rich. Impoverished Jews there were so abused by their wealthy co-religionists that 80 poor families converted to Protestantism and 2,000 more families threatened to do the same. ${ }^{53}$

48 Rodrigue, French (as in n. 3), p. 28.

49 For Jews in trade, see P.P.A.P., 1866, vol. 1xix, pp. 192-93. For merchant's warehouse, see PRO-FO 78/1986, Charles Calvert to Lord Stanley, 31 July 1867, p. 86. For names of merchants, see BAIU (as in n. 10) (January 1865), p. cxxix.

${ }^{50}$ For millers and other trades, see Konstandinos A. Vakalopoulos, Modern History of Macedonia (1830 D1912) (Barbounakis, Thessaloniki, Greece, 1988), pp. 141-43. For names of bankers, see BAIU (as in n. 10) (January 1865), p. cxxix.

51 For Bazirgan, see Michael Ursinus, Regionale Reformen in Osmanischen Reich am Vorabend der Tanzimat: Reformen der rumelischen Provinzialgouverneure im Gerichtssprengel von Manastir (Bitola) zur Zeit der Herrschaft Sultan Mahmuds II. (1808-39) (K. Schwarz, Berlin, 1982), pp. 219-22.

52 PRO-FO 78/2047, Charles Calvert to Lord Stanley, 15 April 1868, pp. 94-95.

53 Avner Levi, 'Shavat Aniim: Social Cleavage, Class War and Leadership in the Sephardi Community - The Case of Izmir, 1847', in Aron Rodrigue, ed., Ottoman and Turkish Jewry: Community and Leadership (Indiana University Press, Bloomington, 1992), pp. 184, 188, 196. 
Large scale charity in Monastir testifies again to the strength of the community's traditional culture. Admonitions to help the poor have been a prominent part of Jewish ethics since the days of the prophets. Sephardic folktales also emphasised charity toward the poor, and in one such conseja from Monastir a rich miser dies and brings his money with him to the afterlife only to discover that it is useless there. He suffers from hunger in the next world and 'appears to his children in a dream and instructs them to distribute the remainder of his fortune among the poor, for he has learned that lack of charity during one's lifetime makes for unbearable conditions after death', ${ }^{54}$

\section{Dissatisfaction of Monastir's Jewish Elite}

The tension between the Westernised culture of Monastir and the traditional Sephardic culture of the Jewish quarter was most keenly felt by Monastir's small class of Jewish merchants. It was they who most fully participated in both worlds, and it was they who experienced the two cultures' material strengths and weaknesses as they directed money made in Monastir to the poor of the Jewish quarter. Not surprisingly, despite the impressive charitable efforts of Monastir's Jewish elite, the rich would prove to be unreliable defenders of tradition. Their business success depended upon their knowledge of European languages and ideas, and this made them the natural allies of the modern schools championed by west European Jews from 1840 onward. It was also in the financial interests of the affluent to lift their communities out of poverty through modern schooling. Widespread poverty placed an enormous burden on the wealthy, and modern schools promised to equip young Sephardim for success in a Europeanised Ottoman Empire and so lessen the need for their charitable support.

Evidence of a desire among some Monastir Jews to abandon the traditional Talmud Torah educational system surfaces in an 1860 report by the missionary Rev. Epstein. On November 14 that year, four months after the founding of the Alliance, Epstein wrote that among the Monastir Jews 'a school for boys and girls might perhaps succeed here more than any other agency; there is a desire on the part of some for educational privileges and in a short time the same may be begotten in others'. Epstein observed a policy of unusual frankness that makes him a reliable source. He was quite open about his failure to win converts, and in May 1862 resigned his post because 'he did not feel that with a good conscience he could continue to remain there in receipt of a salary', while failing to win converts to Christ. ${ }^{55}$

The interest in education for girls clearly suggests that the combination of Ottoman reforms and Western Jewish insistence on educational innovations

${ }^{54}$ Reginetta Haboucha, 'Societal Values in the Judeo-Spanish Folktales', in Dov Noy and Frank Talmage, eds, Studies in Jewish Folklore: proceedings of a regional conference of the Association for Jewish Studies held at the Spertus College of Judaica, Chicago, May 1-3, 1977 (The Association, Cambridge, 1980), pp. 165, 170.

55 Presbyterian (as in n. 18) 14:2 (February 1861), p. 22; The Acts and Proceedings of the Synod of the Presbyterian Church of Canada in Connection with the Church of Scotland (Montreal, 1862), session xxxiv, p. 58. 
were starting to affect Monastir. Monastir's Jews were beginning to look for and find a place for themselves outside Jewish society. As early as 1857, the city's French Catholic mission school counted two Sephardic girls among its students. ${ }^{56}$ The appointment of Jews to salaried positions on town councils, provided for in the 1856 reform, also distanced individual Jews from community control, and by 1860 a Monastir Jew sat on a local commercial council. Monastir's bankers and merchants had regular dealings with the European businessmen in town, and some, such as the banker Solomon Nahama, spoke Turkish and even some French. ${ }^{57}$

These scraps of evidence point to two important facts: that even before the 1863 fire a few Monastir Jews had begun to drift from traditional Sephardic life, and that this trend was limited and unorganised. Until the fire, the community's traditional structure held sway and no group of reformers formally broke with community norms.

\section{The Fire of 1863}

At 4 p.m. on 14 August 1863, after weeks of drought, guns were fired at the Monastir battery. ${ }^{58}$ It was a fire alarm. The blaze began in a small tavern and soon spread to nearby houses. In a letter dated August 20, British consul Charles Calvert described the town's fire fighting efforts.

The Civil Authorities, with the entire local corps of police, and the Military Authorities with several detachments of troops, each provided with fire-engines and implements for pulling down wooden buildings, however early on the spot, were unable to check the spread of the flames. Unfortunately, owing to the recent drought, water was exceedingly scarce, and the little water that was available proved all but useless in the face of a conflagration which, from the beginning, possessed a character of irresistible ascendancy. ${ }^{59}$

Monastir's Jewish quarter with its wooden homes was virtually wiped out. Of the 232 homes lost to the fire, 190 were in the Jewish quarter, while the Christians lost 35 houses and the Turks only seven. The 190 lost homes represented more than 90 percent of the Jewish quarter. A mere 15 Jewish homes survived. Because as many as five families shared one house, about 600 families, or 3,000 people, lost their homes in the fire. This number accounted for virtually the entire Monastir Jewish community. The Jews' six synagogues and houses of study were also destroyed, as was the Talmud Torah school. ${ }^{60}$

For sympathetic observers, the destruction of Monastir's bazaar, bridges,

56 Archives, Congregation de la Mission (Paris), Arthur Droulez, Histoire de la Mission Lazariste de Monastir (Bitolj), 1857-1930 (Istanbul, 1943), p. 12.

57 Karmi, Jewish (as in n. 30), p. 83. For Nahama, see Isaac Nehama to Mark Cohen, 25 March 2002.

58 For alarm guns and hour, see HFMR (as in n. 41), 1 Oct. 1863, p. 175. To reconcile Turkish and European time, see Presbyterian (as in n. 18) 14:5 (May 1861), p. 68.

59 PRO-FO 78/1764 (as in n. 12), Calvert to Russell, p. $239 \mathrm{ff}$.

60 Ibid.; Jewish Chronicle, 25 Sept. 1863, p. 5. For Talmud Torah, see Archives, The Board (as in n. 37), entry beginning, 'Letter read from Consul Calvert dated from Monastir 25th March.' For wooden homes, see Yerolympos, Urban (as in n. 17), p. 14. 
inns, and clock tower paled in comparison to the human suffering inflicted on the Jews. While Consul Calvert mourned the fact that 'the commercial prosperity of Monastir has, through this calamity, received a blow from which it will take at least 20 years to recover', he also noted that just days before the fire many Monastir merchants had relocated their goods to a fair in nearby Prilep, saving their wares from destruction. There was no such silver lining for the Jews. Calvert described their bleak situation in his August 20 letter.

The almost total destruction of their quarter has reduced upwards of six hundred Jewish families to a state of great misery and destitution. Up to the present time the government Authorities have issued a thousand loaves of bread a day; and another thousand daily have been provided by private contributions; this supply, however, barely suffices to keep the most necessitous from starvation; others contrive for the present to live upon their own scanty resources, which must sooner or later be exhausted.

But, above all other considerations, anxiety for the future must predominate; since some kind of provision must be made, as well for housing and warming, as for feeding, these miserable people, during the approaching winter. For the present, some hundreds of them are crowded together in the tents provided by the Government; others live in the open air under trees; and as many as have been able to afford to pay rent have got into private houses. ${ }^{61}$

The Scottish missionary to the Jews, Rev. Stober, was especially grieved by their predicament and he devoted himself to treating the many who fell ill due to inadequate food and shelter. Stober daily visited more than 30 sick Jews in their 'miserable sheds and overcrowded rooms' ${ }^{62}$ Conditions were so bad that the Jews came down with typhoid. ${ }^{63}$ In a letter of August 20, which appeared in The Church of Scotland Home and Foreign Missionary Record on October 1, 1863, Stober pleaded for help and conveyed the anguish he felt at the Jews' dire circumstances.

I beg you that you will make their case known to all friends of Israel- to all who have hearts to feel for the old people of God. Help, dear friends, help us soon, that these wretched people may get shelter and warm clothing before winter. ${ }^{64}$

In the days after the fire, the Jews survived thanks to bread and tents provided by the Ottoman authorities and charitable residents of Monastir. Stober's pleas for help also produced results. In addition to his published appeal, Stober sought funds from Church members in Germany and Britain. These appeals were not in vain, and the funds he raised allowed Stober to distribute money and medicine to the Jews. ${ }^{65}$

\footnotetext{
61 PRO-FO 78/1764 (as in n. 12), Calvert to Russell, pp. 239-42.

62 HFMR (as in n. 41), 1 Feb. 1865, p. 276, and 1 March 1865, p. 297.

63 For typhoid, see ACS (as in n. 45), minute book, Dep 298/207, entry dated 11 Jan. 1865, n.p.

64 HFMR (as in n. 41), 1 Oct. 1863, p. 175.

65 ACS (as in n. 45), minute book, Dep 298/207, p. 51.
} 


\section{Rescue and Rebuke-London's Jews respond to the Monastir Disaster}

While Ottoman and Christian aid was important, the greatest help for Monastir's Jews came from fellow Jews. The Chief Rabbi of Monastir, Rav Jacob Joseph Israel, along with other community leaders, wrote a letter of appeal to Sir Moses Montefiore of London, one of the wealthiest Jews of his day and also one of the most devoted to the welfare of his fellow Jews. Over the course of his extraordinary 100-year life, Montefiore set out on numerous special missions of help and rescue to the Jews of Damascus, Morocco, Russia, Turkey, and Rumania, and he made seven visits to the Jewish community in Jerusalem. As the historian David Littman wrote,

His social contacts with Britain's ruling classes, from prime ministers down, his important financial position, his close relationship with the senior Rothschilds by marriage and his presidency of the Board of Deputies of British Jews gave him a unique position of authority at home and abroad. ${ }^{66}$

Montefiore was known to the Sephardim of the Ottoman Empire at least since the Damascus Affair of 1840, and his high profile among the Ottoman Sephardim was reinforced in May 1863, just three months before the Monastir fire, when Montefiore again met with the sultan in Istanbul and received a special proclamation assuring the Jews of equal rights. ${ }^{67}$

This was the man Monastir's Jews addressed in their letter, which was written in Hebrew and dated 5th Elul 5623 (20 August 1863). Consul Calvert forwarded the letter to London along with a supporting note of his own the same day, and Montefiore received the letters on 17 September. This is the letter Montefiore received from Monastir's Jews as it was published in translation in London's Jewish Chronicle newspaper on 25 September 1863:

To Sir Moses Montefiore, \&c., \&c.

After having invoked blessings on your head, we acquaint you that alas, alas! a fire from Heaven has visited our city, and has consumed our beautiful synagogues and houses of study; and our young and old wander about the streets naked, and in the greatest destitution, and women brought up delicately go about bare-footed and without garments.

The voice of the law is heard lamenting, because there is no place now for its study.

We are all reduced to the greatest misery; for our beautiful city has become a prey to the flames; only about fifteen houses have escaped.

And now, to whom are we to turn our eyes for help, but to our Father in Heaven, who has pity on all His creatures, and to him who has been privileged to assist so many.

We implore you to extend to us a helping hand, and to speak to the chiefs and charitable of your city, that they may look upon us with benevolence, and bestow upon us some of the blessings wherewith God has blessed them, and

\footnotetext{
66 David Littman, 'Mission to Morocco (1863-1864)', in Sonia and V. D. Lipman, eds, The Century of Moses Montefiore (Oxford University Press, Oxford, 1985), p. 176.

${ }^{67}$ Ibid., p. 177.
} 
thus assist us in repairing the damage done. ${ }^{68}$

The Monastir Jews could not have known it, but their letter arrived on Montefiore's desk at a propitious moment. During the previous four weeks, the editors of the Jewish Chronicle had published scathing critiques of the Board of Deputies. The barrage of criticism began in the 14 August issue, when the newspaper learned that the Board had ignored appeals from the impoverished and threatened Jewish communities of Sana, Yemen, and the Greek Ionian Islands.

Is such the working of the feeling of brotherhood which should unite in one close bond co-religionist to co-religionist? Has the tie of a religion in common become so loosened in the Anglo-Jewish heart as not even to awaken the sentiment of common benevolence, as not even to impel it to make the slightest effort for the rescue of the drowning, struggling in the waves, apparently within the reach of those able to help, if they would? ${ }^{69}$

This theme was repeated the following week in the 21 August issue, and on 18 September, one week before the Monastir story appeared in its pages, the Jewish Chronicle again dismissed the Board's activities when it introduced the Board's 'Third Half-Yearly Report' by writing, 'This, we believe, is the meagerest $[\mathrm{sic}]$ report of the Board that has ever come under our notice'. ${ }^{70}$

The call for help that arrived from Monastir on 17 September offered the Board a chance to redeem itself, and Montefiore acted immediately upon his receipt of the letter. Rushing to issue an appeal to British Jewry before the Yom Kippur holiday, which fell on 23 September that year, Montefiore on 18 September wrote to the London Committee of the Board and urged all of London's rabbis to make Monastir the focus of a fundraising appeal to their congregations on the upcoming fast day. Fliers which reprinted the letter from Monastir, along with the letters of support from Calvert and Montefiore, were distributed to all of London's synagogues. The Jewish Chronicle noticed the Board's new attentiveness and, perhaps affected by the spirit of repentance and forgiveness of the holiday season, wrote in its 25 September issue that since it had criticised the Board's earlier inaction, it is 'therefore but right that we should commend it for the promptitude with which it acted on a recent emergency, when its ear was reached by a lamentable cry of woful [sic] distress. It was only on the evening of the 17th that the account of the calamity at Monastir, described in another column, came to the knowledge of the Board. Yet on the morrow the Board had not only met, but issued its appeal to all the congregations in the kingdom'. ${ }^{71}$

Montefiore's letter to the London Committee of the Board also appeared in the 25 September Jewish Chronicle. He wrote,

My Dear Sir,

I feel it is my duty, without one moment's delay, to call your attention to the

68 Jewish Chronicle, 25 Sept. 1863, p. 5.

${ }^{69}$ Ibid., 14 Aug. 1863, p. 4.

70 Ibid., 21 Aug. 1863, p. 4, and 18 Sept. 1863, p. 5.

71 Ibid., 25 Sept. 1863, p. 4. 
accompanying letters, describing the piteous calamity which has just befallen our brethren in Monastir.

I feel assured that the Board will hasten to make known the melancholy intelligence to the several synagogues in the kingdom, and request the authorities to cooperate in organising a movement to mitigate, as far as in us lies, the dreadful distress of the helpless sufferers; and I would respectfully suggest that a stirring appeal be made by our reverend preachers on the approaching Fast of Atonement, and that special offerings be made in every synagogue on that solemn day; and surely an appeal in the house of God to our more prosperous brethrennever made in vain - will, on a day when Charity, as set forth in our holy ritual, is regarded as one of the three pillars on which atonement rests, be attended, under God's blessing, with the best and happiest results.

I request you will be pleased to receive the enclosed $£ 20$ - a contribution to the fund, in memory of my deeply-lamented wife, Judith, Lady Montefiore.

I remain, my dear sir, yours faithfully,

Moses Montefiore. ${ }^{72}$

All of London Jewry responded. On Yom Kippur, London's Jews learned of the fire and the homeless Jews of Monastir. Rabbis made speeches, announcements were posted, and the weekly Jewish Chronicle reported on the Monastir story for more than a month. ${ }^{73}$ At London's Spanish and Portuguese Jews' Congregation a special session of the Board of Elders was convened to approve the raising of money for Monastir on Yom Kippur. In addition, the Board of Elders approved an immediate grant of $£ 100$ from the Fund of Cautivos, which provided money to ransom captives and help victims of disasters. The pressure to donate money was so strong that the one London synagogue that did not make a contribution was chastised by the Jewish Chronicle for its 'act of selfish indifference'. ${ }^{74}$ The public shaming led the Bayswater Synagogue to make a donation.

London's Jews contributed approximately $£ 2,000$ toward the relief of the Jews of Monastir, a large sum in its day. Through the remainder of 1863 and the spring of 1864 the money raised in England purchased food, clothing, and shelter for the Monastir Jews. Money was also given to Monastir's Chief Rabbi so that he could rebuild and furnish his house. ${ }^{75}$ But London would not permit the community to use the money to rebuild its synagogues and schools. For Monastir's Jews the destruction of their synagogues was one of the chief losses they mentioned in their letter to Montefiore, and Monastir's Jewish leaders were intent on rebuilding these crucial community assets. London insisted the money be spent only on humanitarian relief.

London's refusal to help rebuild Monastir's schools and synagogues high-

72 Ibid.

73 Ibid., 25 Sept., 2 Oct., 9 Oct., 23 Oct. and 6 Nov. 1863.

74 Archives, Spanish and Portuguese Jews' Congregation (London), minute book of the Board of Elders. Entry dated 8th Tisry 5624. For chastisement of Bayswater, see Jewish Chronicle, 2 Oct. 1863 , p. 6.

75 For the amount raised, see HFMR (as in n. 41), 1 March 1865, p. 297. For rebuilding of rabbi's home, see Archives, Board of Deputies of British Jews, Legal and Parliamentary Committee, minute book, ACC/3121/C13/1/3, minutes of meetings held 31 Nov. 1863 and 1 Dec. 1863. Also see The Board (as in n. 37), entry beginning, 'Read a letter from Consul Calvert enclosing a balance sheet.' 
lights the enormous differences that existed between Ottoman and Western Jewry in the mid-nineteenth century. In England, traditional Jewish life had already receded as the Jews gained civil rights and participated in the national culture and language. They lived Jewish lives quite different from those of the Ottoman Sephardim, for whom Jewish identity was total, involving religion, language, custom and residence. ${ }^{76}$ As outlined above, even the London Jews most dedicated to the welfare of the Ottoman Jews had little patience with Sephardic traditionalism. Montefiore himself, despite his energetic and even heroic efforts to help the Ottoman Jews, had no sympathy for the traditional Sephardic schooling he witnessed when he visited Istanbul in 1840. French Jewry's main body, the Central Consistory, had announced in 1854 that it would direct 'the work of civilizing the Jews of the Orient', the Alliance in 1860 announced that it would 'enlighten those who have been blinded', and by 1862 the Alliance and the Board of Deputies were in discussions to open a modern school for the Jews of Tetuan, Morocco. ${ }^{77}$

Given this zeal for reform, it is no surprise that London's Jews refused to help rebuild Monastir's synagogues and religious school. They wanted to transform those institutions, not preserve them. Montefiore's nephew, Joseph Mayer, chaired the committee that denied the aid. The minutes of the London Jews' meeting, held on 31 November 1863, make it clear that they had no qualms about refusing Monastir's request.

[The President] reported that he had received a letter from Mr. Calvert, HM's [her Majesty's] Consul at Monastir, dated 22 Oct. last, as to the difficulty of organizing a committee of relief \& as to the desire of the Elders of the Community to apply part of the Subscriptions toward a Building Fund for the reerection (sic) of Synagogues \& Schools, but that in his opinion the whole of the Subscription [illegible] be applied for food clothing lodging \& c for the destitute poor,

The Committee was of the same opinion \& Mr. Montefiore was empowered to write to Mr. Calvert to that effect. ${ }^{78}$

This revealing passage deserves close attention for what it says about the congruence of values that existed between English Jew and gentile, the lack of same between English Jew and Ottoman, the paternalism that governed relations between the latter, and finally the difference in tone and emotion between this private communication and the public one printed in the Jewish Chronicle.

First, it is important to note something so obvious it might be overlooked: after the arrival of the Monastir Jews' letter, the London Committee of the Board of Deputies had no direct dealings with the Monastir Jews. As the passage makes clear, the committee maintained a correspondence with Monastir's Consul Calvert. It can be assumed that Calvert himself did not find it easy to communicate with the Monastir Jews, and that it might have been easier for the Jews of London and Monastir to write to each other in Hebrew, which was

76 Rodrigue, 'Beginnings' (as in n. 8), p. 440.

77 Rodrigue, French (as in n. 3), pp. 15, 22-23.

78 Archives, The Board (as in n. 37), minutes of a meeting held 31 Nov. 1863. 
the language the Monastir Jews employed in their letter to Montefiore. But though both communities shared the Hebrew language, they did not share the values that common possession of the Jewish language implied. London's Jews had more in common with Calvert. He suggested that Monastir's Jewish synagogues and schools receive no money, and London's Jews agreed. The Board registered no Jewish shock or umbrage at Calvert's suggestion that Jewish schools and synagogues go begging. The English-language correspondence between Calvert and the Board of Deputies accurately reflected their common outlook, as well as the estrangement of both from the world of the Ottoman Jew.

The report also reveals a parity of status between Calvert and the Board, and the paternalistic posture of both toward the Monastir Jews. The London Jews did not hand over their charitable funds to Monastir's Jewish community. Instead, they entrusted the contributions to Consul Calvert, conferred with him, and through him controlled how the money was spent. The Board even advised Calvert to put the community on an allowance. The flow of relief monies was restricted to $£ 10$ a week and later raised to $£ 25$ or $£ 30$ 'at $\mathrm{Mr}$. Calvert's discretion' ${ }^{79}$ Monastir's Jews exercised no discretion and were in the embarrassing and childish position of having to ask permission to fund projects. With the aid of Calvert, the London Jews transformed simple charity into an instrument of power that could influence Monastir's future and humble its leaders.

Finally, the difference in the tone of Montefiore's public letter to the Board of Deputies regarding Monastir, and that of the committee's private minutes, is striking. Montefiore made an emotional appeal that referred to the 'piteous calamity' in Monastir and 'the dreadful distress of the helpless sufferers'. No emotional words were recorded in the committee minutes cited above. And this difference can not be attributed solely to the nature of committee minutes. On 21 September 1863, a special meeting was held at London's Spanish and Portuguese Jews' Congregation regarding the Monastir Jews. The congregation's minute book recorded that the 'Mahamad [Board of Elders] have felt it their duty to call you together in order to lay before you a communication received by the Board of Deputies, on the awful calamity which has unhappily fallen on our Brethren in the Town of Monastir' (emphasis added). ${ }^{80}$

In fact, the difference in tone between Montefiore's public and the Board's private communications suggests that, in this case, Montefiore chose to conceal his true feelings toward Ottoman Jewry. Though since 1840 there had been many sharp-tongued reports in the Jewish press about the Eastern Jew, Montefiore chose to be publicly sentimental about Monastir. He would issue no rebuke, as he had in Istanbul in 1840. Monastir's Jews had suffered a disaster, and the criticism of the Jewish Chronicle needed to be neutralised. Whether it was a subterfuge or just common sense, Montefiore's public comments had an effect he surely must have welcomed. The Jewish Chronicle com-

\footnotetext{
79 Ibid. Entry beginning, 'Read the correspondence which has passed between the Board and Mr. Calvert.'

${ }^{80}$ Archives, Spanish (as in n. 74). Entry dated 8th Tisry 5624.
} 
plimented the Board's humanitarian response to the Monastir crisis, and behind closed doors the policy to reform Ottoman Jewish education proceeded apace. News of the Board's decision to deny aid to Monastir's schools and synagogues never appeared in the Jewish Chronicle.

Following the Damascus Affair of 1840, Montefiore and other leading Western Jews advocated modernising Ottoman Jewish schools, which they viewed as backward and as a cause of Sephardic poverty. But even given this history, the Monastir incident contributes to a deeper understanding of just how deeply this antipathy ran. Monastir Jewry was desperate and in misery, but Western Jewry remained unbending in its disapproval of traditional Sephardic observance and education. London's actions were a signal to the Monastir Jews that the time had come to break with traditional education, and there were some in Monastir who were receptive to this message and who acted upon it. The fire thus marked the beginning of the complete transformation of the traditional world of the Monastir Jews.

\section{Monastir forms an Alliance Committee}

The fire created two main conditions that favoured the creation of an Alliance committee, with the most obvious being the impoverishment of the Monastir Jews. Alliance schooling won over the Ottoman Sephardim with the prospect of a better life, and after the fire Monastir's Jews were desperate for such a prospect. If before 1863 the poverty of Monastir's Sephardim could be ameliorated through tzedakah, afterward it must have been clear that more radical measures were needed. French instruction at an Alliance school would give young Monastir Jews the tools they needed to escape poverty.

But the fire did not merely heighten the Monastir Jews' need for Western education, it also weakened rabbinical opposition to such education. In 1863, such opposition was still widespread and powerful. Though the Ottoman state took steps to support Istanbul's reformers against rabbinical opponents in 1856 and 1862, apathy toward its small Jewish community was the main determinant of Ottoman policy toward the Jews. Formal regulations to strengthen reformers and weaken rabbinical power were not passed until 1865, and even these were not actively enforced. ${ }^{81}$ But in Monastir the fire achieved the same ends. After the fire Jews left their ruined quarter for other parts of town. Some moved to an area known as Ine Bey and others, such as one Muschon Calderon, had by mid-October moved to the Emin Chelebi quarter. ${ }^{82}$ Rabbinical supervision of the community, so easy in the Jewish quarter, became almost impossible. Invariably, after Ottoman Jews left their residential quarters, the release from direct rabbinical oversight allowed

\footnotetext{
81 Rodrigue, French (as in n. 3), pp. 42-43.

82 For Ine Bey quarter, see Dimovski-Colev, Bitola (as in n. 2), p. 35. For Emin Chelebi quarter, see Johann G. von Hahn, Reise durch die Gebiete des Drin und Wardar im auftrage der Kaiserl. Akademie der wissenschaften, unternommen im jahre 1863 (Akademie der wissenschaften, Vienna, 1867), p. 348.
} 
Jews 'to behave differently and offered them choices in education, recreation, and social relations'. ${ }^{83}$

London's actions strongly exaggerated the effect of both of these repercussions of the fire. The poverty caused by the fire would in any case have likely led Monastir's reformers to consider founding an Alliance committee, but London's actions made turning to the Alliance an economic necessity. When Montefiore embraced Monastir's cause and inaugurated a fund raising campaign that eventually raised $£ 2,000$, he demonstrated that there was indeed money available even for small communities such as Monastir. But when the Board of Deputies refused to fund the rebuilding of Monastir's Talmud Torah, it became clear that Monastir could lose funding opportunities if it did not develop acceptable institutions. In fact, the Monastir Jews formed its Alliance committee in July 1864 only after several failed attempts to win additional funding from the Board. In May 1864, months after the Board's initial refusal to fund synagogues and schools, the Monastir Jews again wrote London, as the Board's minutes note, 'with respect to the appropriation of the Balance [of the funds] \& stating their inability to rebuild their Synagogues as that despite all their exertions [they] could only raise sufficient means to reerect (sic) two houses of study and the Talmud Torah school they hoped to have consecrated by Passover [1865], ${ }^{84}$

The passage indicates that the Monastir community resorted to a triage approach to its problems and funded the Talmud Torah at the expense of the synagogues. The Board's staunch refusal to fund traditional religious institutions was crippling the community's ability to function. London's tantalisingly close yet inaccessible funds brilliantly highlighted the need for Monastir to adopt institutions, such as the Alliance, that were favoured by European Jewry.

The Board also further weakened the rabbinical power that was already severely shaken by the fire. Not only were the rabbis faced with the difficulty of overseeing a dispersed community, they suffered the public humiliation of having their funding requests refused. London's indifference toward the fate of Monastir's Talmud Torah school and synagogues could only have been interpreted, correctly, as a vote of support for the agenda of Monastir's Westernised elite, who at least since 1860 had voiced support for modern schools. The prestige of Europe's most famous benefactor of the Ottoman Sephardim was thrown behind these reformers. Monastir's rabbis wrote to Montefiore for help and he strengthened the hand of their adversaries.

The dispersal of the community and the rebuttal by London brought about the de facto end of rabbinical authority in the Monastir community. From 1864 onwards, bankers and other businessmen set the direction for the

\footnotetext{
${ }^{83}$ Yerolympos, 'New' (as in n. 33), p. 626.

84 Archives, The Board (as in n. 37), entry beginning, 'Letter read from Consul Calvert dated from Monastir 25th March.'
} 
community's future. $^{85}$

All of these post-fire events took place in an atmosphere conducive to Westernisation. Monastir's non-Jewish communities were also undergoing educational reform. The Bulgarian-Greek rivalry that began in the 1850s resulted in separate schools for each group. Monastir's Catholic mission organised a modern Bulgarian school, and the Greeks responded with Community House, a cultural organisation boasting a library and lecture hall. As a result of the 1856 Ottoman reforms, there was also an increasingly Western flavor at Monastir's military schools, and the city's influential Vlach community had long studied German, Italian, and other west European languages. ${ }^{86}$ Monastir's Jews were surrounded by cultural and educational innovation at every turn: internationally from west European Jews, nationally from the Ottoman state, and locally from Monastir's various ethnic groups.

By July 1864, thirteen Monastir Jews participated in this modern education movement when they joined the Alliance and formed a local committee. In late October, three more Monastirlis had joined the Alliance. No rabbis formed a part of this powerful new group. The 16 members included the merchants Salomon Nahman Alevi, Jhiel Nahman Alevi, Joseph Mose Orgas, Joseph Haim Perres, and Jacob Rahamim Nahmias; the bankers Avissay Raphael Alevi, Mair Abraham Alevi, Salomon Abraham Camhi, Haim Benjamin Estrumtza, Salomon Isaac Frances, Nahman Jacob Mulia, Salomon Bouhor Nahama, Salomon-Abraam Sarfati and Aron Nessim; and two teachers, Isaac Gabriel Acoen and Mose Salomon Camhi ${ }^{87}$ Significantly, most of these members have Sephardic names. While the Empire's Italian Jews were the main local force backing educational reform at this time, in Monastir there were some Sephardim who were comparably Westernised.

\section{Conclusion}

Monastir's Alliance committee began an association with the Paris-based organisation that continued for the next sixty years. Over that time, the Alliance and its local supporters founded new schools, instituted apprenticeship programmes where young men could learn trades, and even came to control and revamp the curriculum of the Talmud Torah school. These events started in

\footnotetext{
85 For example, Jacob Joseph Israel, Monastir's chief rabbi through 1889, does not appear on any Alliance committees or boards. Because the founding of Alliance schools required extensive funding and involved a revolution in the education of boys and girls, it was the most important project undertaken by the community in the late nineteenth century. The rabbi's absence from Alliance committees speaks to his growing irrelevance in an increasingly Westernised community. For Monastir Alliance committee lists, see BAIU (as in n. 10) 1st semester 1874, pp. 111-12, 128 29; BAIU 2nd semester 1878, pp. 67, 76; and BAIU 9, second series (2nd semester 1884 to 1st semester 1885), p. 162.

86 Annales (as in n. 13) 38 (1873), p. 220; Papadopoulos, 'Ecoles' (as in n. 26), pp. 401-402; Ralston, Importing (as in n. 27), p. 64; Hahn, Reise (as in n. 24), p. 118; Grigorovich, Ocherk (as in n. 17), p. 95.

87 BAIU (as in n. 10), October 1864, p. 7, and January 1865, pp. 2, cxxix. The October report includes news received on 4 August, so I date the committee from July.
} 
the early $1880 \mathrm{~s} .{ }^{88}$ In the early years of the Alliance, the organisation depended upon local communities to subsidise a great percentage of a school's cost, and few could afford the expense. As a result, even the large Sephardic communities of Salonika, Istanbul, and Izmir did not found Alliance schools until the early $1870 \mathrm{~s} .{ }^{89}$ But despite the delay, Monastir's 1864 Alliance committee was enormously important because it was the community's first formal break with traditional religious life and its institutions. The value of a Talmud Torah education could not be measured in worldly terms. Its purpose was to transmit the law given by God to the people of Israel. Alliance schools held out the promise of learning French and succeeding economically. By transferring their allegiance to the Alliance, the committee members revealed that a radical shift in values was in progress.

London's Board of Deputies succeeded in spurring this change in Monastir by undermining the prestige and power of the community's rabbinate and financially starving its Talmud Torah school. This was in keeping with the aims Montefiore had expressed since 1840. But London's actions also seem to have had unintended consequences.

The Church of Scotland's Rev. Stober was a great aid to the Monastir Jews after the fire as he distributed charitable help and treated the sick. He also continually preached Christianity. In a letter dated 17 November 1864, Stober wrote:

On the Jewish Sabbath I read with several the passages in the Old Testament they have read in the synagogue, entering into conversation with them about the proper interpretation. With the Hacham [rabbi] ... I read on two evenings each week the New Testament, a work which brings great joy to me and no less to him. At one of our last meetings we read the tenth chapter of St. Matthew. When he came to the 21st verse he became quite excited with joy, and said, 'Our wise men hold that such things must take place on the coming of the Messiah; how remarkably has everything been fulfilled!' He quite agreed when I said that it was just on this account that the Jews were forbidden by the Rabbis to read the New Testament. ${ }^{90}$

The account appears credible, especially because in the same letter Stober admitted facing a 'spirit of opposition' from the Jewish community. ${ }^{91} \mathrm{Op}$ position suggests that the missionary work met with some success. Stober's selfless devotion to the Jews after the fire must have spoken well of the man, and given his zeal to convert and the Jews' desperate need for help, it is likely that he had some influence. It is also possible that Stober's job was made

${ }^{88}$ For schools in early 1880 s, see BAIU (as in n. 10), no. 7, second series (second semester 1883), p. 32. For founding of official Alliance schools, see Narcisse Leven, Cinquante Ans D'histoire: L'Alliance Israélite Universelle (1860-1910), vol. 2, pp. 183-84. For apprenticeships, see Lebl, Ge'ut (as in n. 2), p. 126. For control of Talmud Torah, see Archives, Alliance Israélite Universelle (hereafter AAIU), Yougoslavie, Monastir, IE4, letter of Abram Misrachi, 6 November 1903.

89 Rodrigue, French (as in n. 3), p. 49; Aron Rodrigue, Images of Sephardi and Eastern Jewries in Transition: The Teachers of the Alliance Israélite Universelle, 1860-1939 (University of Washington Press, Seattle/London, 1993), pp. 16, 20-21.

90 HFMR (as in n. 41), 1 March 1865, p. 297.

91 ACS (as in n. 45), Dep 298/207, p. 123. 
easier by London Jewry's hostility to the religious needs of Monastir's Jews. While London focused on the Jews' material needs, Stober offered religious comfort. In 1864, Stober evaluated his progress. 'As to your missionary work ... I think I may venture to say the first step has now been gained; we have access to every Jewish family, from the Grand Rabbi to the poorest in the community'. ${ }^{92}$

Stober's teachings had a lasting impact on at least a few Jews. In 1873, eight years after Stober's death, a new agent of the Scottish mission reported that two Jews who were Stober's friends were 'considerably well informed as to Christian truth. They know the Gospels, which we read together' ${ }^{93}$ It seems that Stober's missionary work after the fire was more successful than Rev. Epstein's had been before it. London Jewry and the Church of Scotland both pursued their separate yet oddly complementary agendas in Monastir after the fire, and both met with success. That success suggests how great a turning point the fire was for Monastir Jewry.

But it was the Alliance that came to be a long-lasting and powerful force of change in Monastir. Montefiore and London Jewry's determination to shape the conditions that led to Monastir's first Alliance committee provides a compact and dramatic example of the how west European Jews changed Ottoman Sephardic life in the nineteenth century.

92 Ibid., p. 51

93 Ibid., Dep 298/209, report of 1873, letter of Mr Aristides, 1 March 1873, n.p. 